This is the accepted version of Roberts, Ron and Itten, Theodor (2021) Francis Huxley and the human condition. The Psychologist, 34, pp. 68-71. ISSN (print) 0952-8229. The version of record can be accessed at https://thepsychologist.bps.org.uk/volume-34/may/francis-huxley-and-human-condition 
Page 1 of 9

\title{
Francis Huxley and the Human Condition
}

\author{
Ron Roberts \& Theodor Itten
}

"Francis Huxley was the most intellectually adventurous person that I've ever met." (David Napier)

Francis Huxley, born in 1923, was the son of Julian and the nephew of Aldous Huxley. He was also a pioneering social anthropologist, colleague of the maverick psychiatrist Ronald David Laing during the heady and turbulent days of the 1960s and co-founder of Survival International. When he died, in October 2016, his life and work left behind a string of unanswered questions, many of which have relevance for our discipline of psychology in these uncertain and dangerous times.

Huxley, described by his friend Rupert Sheldrake as a "feral intellectual" was enormously quizzical about the human condition. Like many before him, he was acutely aware of the inadequacies of any one discipline to confront it. Psychology is considered by many to be best placed to interrogate - academically at least - the nature of the human condition. Huxley, like many others, was aware of the limitations of this view. My (RR) late friend, the philosopher and artist, Svetlana Boym suggested that perhaps our discipline's primary shortcoming for this task was that it lacked the time and space to tell nuanced individual stories. Too many of us - for perhaps too long - have been subverted by the allencompassing imperative to be not only quintessentially scientific but answerable to the dictates of the, by now deeply entangled, academic-corporate marketplace.

Of course, storytelling still survives amongst our ranks - located as often as not amongst the marginalised - those excluded from the administrative paradise of reason by virtue of class, gender, ethnicity, sexual orientation, disability, profession or assumed morality. I would not claim the aforementioned list is exhaustive! Other than the many who struggle to have their voice heard and their existence recognised, an additional issue is the nature of the stories which their lives beget and the contexts which house them. As I discovered earlier in my own career (RR) when tasked with investigating a pioneering drug rehab in East London, the boundaries within which psychological enquiry proceeds may on occasion come to resemble social anthropology. In social contexts a strategy of reductionism becomes less 
and less successful. Indeed, the crisis in social psychology can be summed up as a conflict between those whose interests lie in discerning the relationships between quantifiable variables and those whose aim is to understand the meanings inherent in the world.

Social anthropology itself, Huxley intuited, required a narrative psychological dimension more than it required a formalised mathematical one. "God" he wrote "as William Blake remarked, is not a mathematical diagram." Francis, was in some respects, trapped within the intellectual fashions of the day and looked to psychoanalysis to provide the requisite 'healing' qualitative psychological dimension. This, he and others surmised, might be capable of supplying the unconscious gel that would bind together healing rituals, religion, the symbolism of the sacred, family structure, the sexual politics of human groups with the human body as the ultimate mediator for the journey undertaken by thought from the murky depths of the unconscious into the full blossom of social life.

Unusual for an anthropologist of his time, Huxley had no interest in utilising Western colonialist categories of thought in order to mould the customs, habits and practices of other cultures into a form which could be comfortingly digested within our own cerebral habits. In this regard he was light years ahead of many of the debates in contemporary academia. He considered it was our duty to adapt to the mental templates of others, to see the world through their eyes rather than the other way round - a direct challenge to the presumed universality of western reason. Laing described the terror which people may have of what their own and others' minds may produce as 'psycho-phobia'. For Huxley, this psycho-phobia was endemic in social science, and the remedy for it was not only to embrace others' ways of seeing but to travel in altered states of consciousness, one form of which, he considered madness to be. To embrace others' ways of seeing however involves more than just a shift in perspective. It is a political act which involves work in two directions. Firstly, it questions the validity of the opposition between self/us and other, as by embracing the position of the 'othered' it ceases to be 'other'; simultaneously this boundary dissolution heralds the dissolution of the familiar comforts of 'home' thought.

But if Huxley's twinning of the 'anthropologised' and othered with madness was bold, there is a very real sense, in which it did not go far enough. It is true that Huxley challenged the colonial imprint abroad, though its domestic variant, racism at home, went unrecognised, 
untheorized and unchallenged throughout the entire radical movement to oppose institutional psychiatry. Any awareness of the pernicious and harmful effects of racism was, during the 1960s, largely confined to its victims and yet there is also a real sense in which an opportunity was missed. Huxley, Laing and David Cooper were visibly present at the Dialectics of Liberation conference in 1968. At this event the Black Power advocate Stokely Carmichael (1968) referred to the "mental violence" and "psychological murder" inflicted by the White West - not only on African people but on Black Americans in the US. In response to this institutionalised violence Carmichael argued there was a need to develop a "revolutionary" and "resistance" consciousness to oppose both the external oppression and people's internalisation of it. Opposition to the violence, Carmichael was clear, did not mean adjustment to it. Despite Carmichael's presence Laing and colleagues continued to theorise the sources of 'psychiatric' disturbance in terms of existential-phenomenological and familial influences, stretching in Laing's case to an awareness that the wider systems in which family life was embedded, including the global capitalist system were an integral part of the context. Carmichael went much further, describing it as "a system of international white supremacy coupled with international capitalism"(above cit p.150).

Racism thus remained 'beyond words' and far from 'obvious' to those crusading against psychological despair and psychiatric tyranny. Laing's key intuition that he was involved in the study of situations, not individuals and Huxley's insight that there were meanings of madness which could usefully be imported from abroad somehow were unable to effectively come together. Perhaps this was because both were already fully occupied fighting against their own effective marginalisation from their respective host disciplines, psychiatry and anthropology. Francis was otherwise well equipped to make the leap, and was acutely aware of the misgivings of colonialism which had emerged in the 1960s. Toni Morrison, some years later summed up what had been overlooked. "The trauma of racism is, for the racist and the victim" she wrote, "the severe fragmentation of the self, and has always seemed to me a cause (not a symptom) of psychosis." (Morrison, 2019, p. 177). These were, she added "strangely of no interest to psychiatry." Until recent years this criticism could equally have been applied to psychology, to the extent to which it remained in awe of biological psychiatry's reductionist declarations. 
So, even as psychoanalysis was brought in to supply some of the missing ingredients to the anthropological enterprise, something profoundly important was missing from it. The failure to explicitly map racism was not the only problem. Huxley's (1985) talk on 'Anthropology and Psychoanalysis' highlighted a number of excesses in the psychoanalytic universe which led to problems in the relationship between the two fields - prominent among them was Freud's insistence on the universality of the Oedipus complex. Although sympathetic, Francis had no hesitation in labelling psychoanalysis a "caricature of...a philosophical system" which had logical inconsistencies with anthropology. A critical dimension, for both Huxley and Laing, was the necessity to add a practical political element to what they were examining.

Huxley and Laing were also able to intuit that while the facts of life appear straightforward enough from a distance - we are born, we age, love, mate, work, play, fight, create and eventually die - these facts do not so much define us as a species as highlight the biological, social, emotional and creative imperatives which orchestrate our existence. Some facts love, sex, birth and death - in their intangible enormity, point to an inescapably spiritual aspect to the human condition. They also supply the ontological foundations upon which psychoanalysis was arguably erected. Faced with the ineffable mystery of existence, politics and the ontology of unending change however, psychoanalysis retreated. Psychology for a long time arguably took the same track. To secure intellectual acceptance it substituted the failed aesthetics of a predictable clockwork biology, predicated on Newtonian mechanics. It did so for reasons which continue to haunt intellectual endeavour in psychology. The craving for acceptance in the halls of establishment thought. Perhaps more than most, Huxley was aware that anthropology offered clues - shamanism (a topic with which he was deeply fascinated) being one of them - that fundamentally different views of reality than those present in Western epistemologies had something useful to offer. To his credit he was prepared to work with the ambiguities which come from living and practising in two seemingly incompatible systems.

Our fledgling individual attempts to craft meaning from our presence in the world are paralleled by the intellectual, psychological and artistic challenges to make sense of the human condition in its entirety - where all these individual strivings merge into a collective 
whole, a puzzle bound by geographical, cultural and historical variations; nothing less than the full range of conditions in which we humans are present and which both shape and in turn are shaped by the world. What Huxley and Laing both realised is that essential as such disciplined attempts are, they necessarily come up short in the face of the inexplicable givens of our existence - both material and existential; what Rebecca Solnit (2006, p.202) described as "the mystery in the middle of the room, the secret in the mirror...what has been there all along." Psychology, like psychoanalysis has largely failed to confront the fact of our existence in the world as ultimately mysterious and that an awareness of this sublime mystery is one of the conditions of being. Many writers have referenced the celebration of this as underpinning what Abraham Maslow called peak emotional experiences. For Baudelaire (2010, p.20), it was "the fantastic reality of life," For Boym (2005, p.503), "the ordinary marvellous," For Arendt, the "miracle" of freedom and for Benjamin (1999, p.63) "the renewal of existence in a hundred unfailing ways." The mysterious nature of being may also lie behind Freud's concept of the uncanny, a realisation of the fundamental strangeness of existing in the world. Adam Kotsko (2015) has considered this uncanniness, 'creepiness' as he designates it, as intrinsic to the enigma of desire - that out significant relationships are founded on a recognition of the 'strangeness', and inalienable differentness of another person. Yet despite all this, there is no place in the psychology curriculum for discussion of the unerringly strange fact of our existence.

Within the broader mystery of our existence are attendant others; our experiential entry and exit points from the world vis-à-vis the birth and presumed death of consciousness, the nature of experienced time, and the place of love in the fabric of the world. These are central to our experience and understanding of life and cannot be resolved by rational means alone - they rather invite an engagement with one's total being, one that in Huxley's (1974, p.3) words "must be acted out in order to be experienced and experienced if one is to make it one's own." In several works he dived headlong into these waters, charting the symbolic roadmaps of world culture, documenting its riches without ever seeking to reduce the map to the semblance of anything more rudimentary. The mysterious, though it is soaked in the world of appearance, is not synonymous with it. In his book the Way of the Sacred, Huxley charted the divine iconography and mythic symbolism of the world which points us toward the invisible source of mystery. It stands as his answer to the question - 
what is the world? It is the world, ready-made, and replete with its own history and peoples that we encounter when we are thrust into it newly born; a phenomenology of human sacred symbolism.

The requisite attitude behind a good deal of Huxley's work is thus a reverence for the unknown, an attitude that is antithetical to the epistemologies currently ordained and worshipped in the church of academia. The instrumental bent of the knowledge industries which circle academia and the kind of information they demand also underscores an aspect of Francis Huxley's life which we have sought to delineate here. Huxley's respect for indigenous peoples, their right to define their own life in the way they choose, their right to be heard, for their voices to be carried into Western academic and political discourse speaks of a demand for knowledge to be allied to justice. The allegiance to any notion of a pure science places considerable obstacles in the way of such a desire. It is no coincidence that it is the qualitative realm where distant voices have been raised. Huxley also accorded people the right to experience the world in a manner consistent with their own customs. Though we now consider it a distinctly post-modern slant, he long ago saw a place for granting different cosmologies rights of co-existence. Raised as he was in the socially privileged bosom of the Huxley clan, educated at Gordonstoun School and Oxford University, the distance he covered intellectually and emotionally, in rejecting the ideologically constructed norms which bolster the mirage of Western superiority cannot be underestimated. We may ask how far our own systems of education encourage us to challenge our own precepts.

In our biography of Francis Huxley (Roberts \& Itten, 2021) we examined the matrix of intellectual, emotional, and social possibilities passed from one generation to another which contained him. For Huxley, as for all of us, escaping that web is not possible but weakening and mitigating its effects is. Francis was at times aware that he was trapped, and in various gambits sought to escape. In many ways his life is a calling card to abandon the traditional premises on which intellectual merit is assessed and on which higher education is founded. Thus, we have agency even if we are not unambiguously free. We can cultivate how to live within the strictures of the given, choose to some extent, using one's inbuilt and acquired resources, what outside influences may be granted entry. He rejected aspects of eugenic thought which his favoured uncle and father endorsed; challenged, both in his narrative anthropology and 
with the creation of Survival International, some of the cultural accoutrements of colonialism and white supremacy; rejected the monotheistic centrepiece of respectable English society, stood apart from the scientism of his esteemed father Julian Huxley and the literary bolthole of his uncle and tried to forge his own way in the world.

Huxley also challenged the instrumental bent of knowledge in another crucial manner. His LSD experiences and research at Weyburn hospital in Saskatchewan accorded love a pivotal place in the human place in the cosmos. Like Chagall, he believed "the meaning of life and art" was "provided by the colour of love." ${ }^{1}$ One can too easily dismiss this as a hangover from the pop philosophy which coursed through the veins of the 1960s. One should look past such fashionable dismissal. Huxley was extremely well read in cultural anthropology and comparative religious thought as well as the wide literature on psychedelia and did not make his pronouncements lightly. He drew attention to an experiential truth which has pervaded world thought for millennia; one which may be as crucial for our own survival and the well-being of the biosphere as the material logistics of selfishness, promoted under conditions of capitalism as a central plank of neo-Darwinian thought. What Darwin imputed into nature, for all its genius, Huxley intuited as arising from Darwin's own masculine tinged view of the world. Huxley was strongly influenced by the suffering his mother endured in her marriage and took a keen interest in the iniquities which women in the world faced. For him, this meant an artistic, even existential appreciation of nature was needed to compliment the excesses of an impersonal view of the natural world. With the intellectual heritage of his great-grandfather weighing heavily on his shoulders, Francis used his anthropological experience and awareness of the often, personal nature of non-Western cosmologies, to balance the formative Huxley picture. His essay on Darwin, published as the 1950s (Huxley 1959/60) drew to a close, remains bold, original and fully contemporary for our age.

The kind of psychology which Huxley championed and which we endorse is a call to broaden the scope of enquiry into the human condition - to forge a greater alliance between psychology, anthropology and the arts; one in which research is fully embedded in an investigator's own conditions of living. In hindsight one can see Huxley's life and work, as a

\footnotetext{
${ }^{1}$ Marc Chagall quoted in Newsweek (1985) April 8th.
} 
Page 8 of 9

fully lived enquiry into the conditions of his own existence - familial, cultural, symbolic and religious, a self-designed anthropological program pursued largely outside of academia. Its outcome is an answer to the twin questions of 'what is the nature of the world?' and 'how do I wish to be known in it?' One can posit this exploration as one's own declaration that without oneself, the world would be incomplete!

The unpredictable and flexible nature of this kind of enquiry, let alone many others, is unlikely to ever find a place in the sanctioned habitats of universities and colleges, already suffocating under the weight of undue regimentation and compartmentalisation of study methods and subjects of enquiry. It is for the convenience of institutions and a deference to tradition that the present arrangements are prioritised above any creative inclination to teach, research and understand the complexities of human life.

All this begs important questions regarding the pursuit of knowledge. Just what kind of knowledge, what kind of enquiry, what programs of learning, what kinds of academics and researchers subscribing to what kinds of values do we want? Must it all be safe, obedient, careful; must we only teach students to follow laid down procedures, capable of guaranteeing pre-ordained results within a specified time period? If so, it will remain the case that the existential and metaphysical dimensions of our existence, not to mention truly liberating commentary or art, will remain off-limits. Then, there will be no place for the Francis Huxley's of this world and any vision for what the fruits of intellectual life can deliver will be correspondingly diminished. Fun and love, were for Huxley, essential to both life and enquiry. It is up to us to include them in what we do.

\section{References}

Baudelaire, C. (2010) The painter of modern life. London. Penguin.

Benjamin, W. (1999) Illuminations. London. Pimilico.

Boym, S. (2005) Poetics and politics of estrangement: Victor Shklovsky and Hannah Arendt. Poetics Today, 26(4), 581-612.

Carmichael, S. (1968) Black Power. In David Cooper (Ed) The Dialectics of Liberation. Harmondsworth. Penguin. 
Huxley, F. (1959/1960) Charles Darwin - Life and Habit. American Scholar, Vol.29, 30, No. 4, 1.

Huxley, F. (1974) The Way of the Sacred. New York. Doubleday.

Huxley, F. (1985) Psychoanalysis and anthropology. In P. Horden (Ed.) Freud and The Humanities, pp.130-151. London. Duckworth.

Kotsko, A. (2015) Creepiness. Winchester. Zero Books.

Morrison, T. (2019) Mouth full of blood. London. Chatto \& Windus.

Roberts, R. and Itten, T. (2021) Francis Huxley and the Human Condition: Anthropology Ancestry and the human condition. London. Routledge. www.francishuxley.com

Solnit, R. (2006) A field guide to getting lost. London. Canongate. 